\title{
Clinical evaluation of shankhapani rasa in the management of kashtartava (dysmenorrhoea)
}

\section{Research article}

\section{Satya Priya $\mathbf{T}^{1^{*}}$, Deeja C.R ${ }^{2}$, Rama Mohan Rao G ${ }^{3}$ Badari Narayana $V^{4}$, Suneela $P^{5}$, Sri Durga $\mathrm{Ch}^{6}$}

1. PG Scholar, Dept of Rasa Shastra, 2. PG Scholar, Dept of Ayurveda siddhanta, 3. HOD and Professor, 4. PG Lecturer, 6. Asst Professor, Dept of Rasa Shastra, 5. Asst Professor, Dept of Prasuti Tantra, SV Ayurvedic College, Tirupati

\begin{abstract}
Menstrual pain which is severe enough to limit normal activities is termed as Kashtartava (dysmenorrhoea). Dysmenorrhoea is the most common gynecological problem faced by women due to abnormal anatomical and functional aspect of uterus, pschycosomatic factors, release of prostaglandins, pelvic congestion etc. Shankhapani Rasa which is a HerboMineral formulation posses all the contents having vatahara and gulmahara properties. The clinal Study was carried out to evaluate the efficacy of Shankhapani Rasa in patients suffering from Kashtartava by selecting 30 patients who attended the O.P.D. and I.P.D. of S.V.Ayurvedic Hospital Tirupathi during the period 2011-2012. Patients were given Shankhapani Rasa in a dose of $125 \mathrm{mg}$ capsules twice in a day for 1 month randomly and effect was evaluated on pre-test and post-test design.Statistically significant $(p<0.01)$ results were seen in Subjective symptoms like pain during menstruation and duration of pain giving a conclusion that Shankhapani Rasa is effective in the management of Kashtartava.
\end{abstract}

Key words: Kashtartava, Herbo-Mineral, Shankhapani Rasa

\section{Introduction}

Menstrual pain which is severe enough to limit normal activities is termed as Kashtartava (Dysmenorrhoea). Dysmenorrhoea is pain with menstruation usually craming in nature and centered in the lower abdomen.It is now estimated that almost $50 \%$ of all women experience some degree of dysmenorrhoea while $10 \%$ were incapacitated by it (1).Severe Dysmenorrhoea is most prevalent in young single women leading sedentary lives and

*Corresponding Author:

T.Satya Priya,

P G Scholar,

S V Ayurvedic College, Tirupathi.

Contact no: 8341088016

Email: satyapriya.dr@gmail.com its incidence becomes higher with the degree of civilization of the community (2). Keeping this in view, it was decided to conduct a study on most prevalent disorder in present times called Kashtartava. The drug chosen for the present study is Shankhapani Rasa, which was mentioned in Sahasrayogam, Gutika Yoga Prakaranam.Here the study is conducted for practical implication and clinical efficacy of Shankhapani Rasa in Kashtartava.

\section{Materials and methods:}

- Patients attending the O.P.D. and I.P.D. of S.V.Ayurvedic Hospital Tirupathi were selected.

- The drug Shankhapani Rasa was prepared in the Department of R.S \& 
B.K, S.V Ayurvedic College, Tirupathi.

- Total 33 patients with signs and symptoms of dysmenorrhea were registered. Out of which 30 patients completed the course of treatment.

\section{Trial drug:}

The drug chosen for the present study is Shankhapani Rasa (3)

Table Showing the Ingredients of Shankhapani Rasa:

\begin{tabular}{|l|l|l|}
\hline $\begin{array}{l}\text { S. } \\
\text { No. }\end{array}$ & $\begin{array}{l}\text { Name of the } \\
\text { drug }\end{array}$ & $\begin{array}{l}\text { Quantity Taken } \\
(\mathrm{gms})\end{array}$ \\
\hline 1. & $\begin{array}{l}\text { Suddha Parada } \\
48(1 \text { pala })\end{array}$ \\
\hline 2. & $\begin{array}{l}\text { Suddha } \\
\text { Gandhaka }\end{array}$ & $48(1$ pala $)$ \\
\hline 3. & $\begin{array}{l}\text { Vatsanabha } \\
\text { Churna }\end{array}$ & $48($ lpala $)$ \\
\hline 4. & Hingu Churna & $96(2$ pala $)$ \\
\hline 5. & $\begin{array}{l}\text { Saindhava } \\
\text { lavana }\end{array}$ & $384(8$ pala $)$ \\
\hline 6. & Chincha Kshara & $384(8$ pala $)$ \\
\hline 7. & $\begin{array}{l}\text { Shankha } \\
\text { Bhasma }\end{array}$ & $384(8$ pala $)$ \\
\hline 8. & Sunthi Churna & $96(2$ pala $)$ \\
\hline 9. & Maricha Churna & $96(2$ pala $)$ \\
\hline 10. & Pippali Churna & $96(2$ pala) \\
\hline 11. & Nimbu Swarasa & Q.S \\
\hline
\end{tabular}

\section{Method of preparation:}

Suddha Parada and Suddha Gandhaka were taken in Khalwa yantra.To this Shodhita Vatsanabhachurna, Hinguchurna, Saindhava lavana, Chincha Ksara, Shankha Bhasma, Trikatu churna were added. Bhavana was done with Nimbu swarasa for one day then dried and filled in $125 \mathrm{mg}$ capsules.

\section{Administration of the drug:}

Mode of administration - orally

Dose $-125 \mathrm{mg}$ twice in a day

Anupana - Hot water
Duration of $\mathrm{t} / \mathrm{t}$ - 1 Month (The drug was started Randomly)

cycles

Follow up- For 2 consecutive

\section{Protocol: Randomized Open Labeled Clinical Trial protocols}

\section{Plan of study}

\section{Aims and objectives:}

The present clinical study has been planned to evaluate the efficacy of Shankapani Rasa in Kashtartava.

\section{Statistical criteria:}

Patients were selected by random sampling technique i.e. irrespective of age, caste, religion \& occupation, they were advised to visit the hospital every 2 weeks for regular check up \& to assess the effect of the therapy there by.In case any patient leaves the treatment without completing 30 days he / she will be declared as dropped out from the research work.

\section{Criteria for inclusion of the patients}

1. Pain during menstruation due to any cause (primary/secondary) except the causes mentioned in exclution criteria.

2. Regular and Irregular cycles.

\section{Criteria for exclusion of the patients}

1. Rakta pradara (Dysmenorrhea with dysfunctional Uterine Bleeding)

2. Malignancies

3. Surgical conditions.

\section{Investigations:}

Laboratory investigations were carried out before and after treatment to rule out any other pathological conditions as well as to record any specific change by the treatment.

\section{Haematological:}

Routine

hematological examinations like total leucocytes count, differential count, hemoglobin percent, 
packed cell volume and erythrocyte sedimentation rate (Wintrobe's corrected method).

Urine: Routine and microscopic examination.

Sonography (U.S.G.): For uterine and adenexal study if needed to rule out any pathology or lesion.

\section{Criteria for assessment of the result:}

The improvement in the patients was assessed mainly on the basis of relief in the signs and symptoms of the disease. To assess the effect of therapy objectively, all the signs and symptoms were given scoring depending upon their severity. Dysmenorrhoea, the cardinal symptom assessed on its severity and duration of persistence.

Assessment of Pain (Dysmenorrhoea): Severity of pain (Multidimensional scoring pattern)

\begin{tabular}{l|l|}
0 & Menstruation is not painful and daily
\end{tabular} activity is unaffected

Menstruation is painful and daily

1 activity is not affected. No analgesic required

Menstruation is painful and daily

2 activity is also affected. Analgesic drugs are needed

Menstruation is painful, she cannot do

3 even her normal routine work and has to absent from class / office during. No effect even by taking analgesics.

\section{Duration}

\begin{tabular}{|l|l|}
\hline 0 & No pain in menstruation \\
\hline 1 & Pain persists for less than 12 hours \\
\hline 2 & Pain continues for $12-24$ hours \\
\hline 3 & Pain continues for more than 24 hours \\
\hline
\end{tabular}

Subjective criteria: Scoring pattern for general symptoms

Table Showing scoring pattern

\begin{tabular}{|l|l|}
\hline None & 0 \\
\hline Mild & 1 \\
\hline Moderate & 2 \\
\hline Severe & 3 \\
\hline
\end{tabular}

Assessment of total effect of therapy:-

On the basis of improvement in the signs and symptoms of Kashtartava, the following criteria were followed to evaluate the total efficacy of the therapy.

Table showing percentage relief obtained by the Therapy:

\begin{tabular}{|l|l|}
\hline $\begin{array}{l}\text { Percentage of } \\
\text { relief }\end{array}$ & Effect \\
\hline$>\mathbf{7 6 \%}$ & Cured \\
\hline $\mathbf{5 1 - 7 5 \%}$ & Markedly improved \\
\hline $\mathbf{2 6 - 5 0 \%}$ & Improved \\
\hline$<\mathbf{2 5 \%}$ & No improvement \\
\hline
\end{tabular}

\section{STATISTICAL EVALUATION OF RESULTS}

The obtained information was analyzed statistically in terms of mean score (x), Standard Deviation (S.D.), Standard Error (S.E.).Paired t-Test was carried out at the level of $0.05,0.01$, and 0.001 of $\mathrm{P}$ levels. For the more effectiveness of therapy paired t-Test is carried out. The results were interpreted as

\begin{tabular}{|l|l|}
\hline a) $\mathrm{P}>0.05$ & : Insignificant \\
\hline b) $\mathrm{P}<0.05$ & : Significant \\
\hline $\begin{array}{l}\text { c) } \mathrm{P}<0.01 \quad \& \\
<0.0001\end{array}$ & : Highly significant \\
\hline
\end{tabular}

\section{Presentation of data:}

The data collected \& analyzed has been depicted in the following sequence:

1. General observations viz. age, occupation, religion etc.

2. Results of therapy evaluated on the basis of improvement in symptomatology. 


\section{OBSERVATIONS AND RESULTS}

1. Age wise distribution:

Table Showing Age wise distribution of Kashtartava in 30 patients

\begin{tabular}{|l|l|l|l|}
\hline S.No. & Age & Number of patients & \% of distribution \\
\hline 1. & $20-30$ & 15 & 50 \\
\hline 2. & $30-40$ & 10 & 33.33 \\
\hline 3. & $40-50$ & 05 & 16.67 \\
\hline
\end{tabular}

Maximum number of patients belongs to age group, 20-30 yrs. (50\%), followed by 30-40 yrs $(33.3 \%)$ and $40-50$ yrs (16.67\%).

2. Religion wise distribution:

Table Showing Religion wise distribution of 30 patients:

\begin{tabular}{|l|l|l|l|}
\hline S.No. & Religion & Number. of Patients & \% of Distribution \\
\hline 1. & Hindu & 25 & 83.33 \\
\hline 2. & Muslim & 05 & 16.67 \\
\hline
\end{tabular}

Maximum number of patients were Hindus (83.33\%) and rest were Muslims (16.67\%).

3. Marital status wise distribution:

Table Showing Marital status wise distribution of 30 patients:

\begin{tabular}{|l|l|l|l|}
\hline S. No. & Marital status & Number of patients & \% of Distribution \\
\hline 1. & Married & 20 & 66.67 \\
\hline 2. & Unmarried & 10 & 33.33 \\
\hline
\end{tabular}

Maximum number of patients were married (66.67 \%) followed by unmarried $(33.33 \%)$.

4. Nature of work wise distribution:

Table Showing Nature of work wise distribution of 30 patients

\begin{tabular}{|l|l|l|l|}
\hline S.No. & Nature of work & Number of patients & \% of distribution \\
\hline 1. & House wife & 15 & $50 \%$ \\
\hline 2. & Student & 10 & $33.33 \%$ \\
\hline 3. & Labour & 5 & $16.67 \%$ \\
\hline
\end{tabular}

Maximum number of patients were housewives (50\%) followed by students $(33.33 \%)$, and labourers $(16.67 \%)$.

5. Food habits wise distribution:

Table Showing Food habits wise distribution of 30 Patients:

\begin{tabular}{|l|l|l|l|}
\hline S.No. & Food Habits & Number of patients & \% of Distribution \\
\hline 1. & Vegetarian & 10 & $33.33 \%$ \\
\hline 2. & Non-vegetarian & 20 & $66.67 \%$ \\
\hline
\end{tabular}

Maximum number of patients were Non Vegetarians $(66.67 \%)$ and rest were vegetarians $(33.33 \%)$.

6. Predominant rasa wise distribution:

Table Showing the Predominant rasa wise distribution of 30 patients:

\begin{tabular}{|l|l|l|l|}
\hline S.No. & Predominant rasa & Number of Patients & \% of Distribution \\
\hline 1. & Madhura-Amla & 8 & $26.67 \%$ \\
\hline 2. & Lavana-Amla & 10 & $33.33 \%$ \\
\hline
\end{tabular}




\begin{tabular}{|l|l|l|l}
3. & Katu-Tikta & 12 & $40 \%$
\end{tabular}

Maximum number of patients were habituated to take Katu-Tikta rasa predominant diet (40\%), followed by Lavana-Amla rasa (33.33\%), Madhura-Lavana rasa $(26.67 \%)$.

7. Constipated Bowel during menstruation wise distribution:

Table Showing the Constipated Bowel wise distribution of 30 patients:

\begin{tabular}{|l|l|l|l|}
\hline S.No. & Constipated Bowel & Number of patients & \% of distribution \\
\hline 1. & Present & 24 & $80 \%$ \\
\hline 2. & Absent & 6 & $20 \%$ \\
\hline
\end{tabular}

Maximum number of patients had Constipated bowels during mentruation (80\%) and rest $(20 \%)$ of patients had no Constipated bowels during menstruation.

8. Chronicity wise distribution:

Table Showing the Chronicity wise distribution of 30 patients:

\begin{tabular}{|l|l|l|l|}
\hline S.No. & Chronicity & $\begin{array}{l}\text { Number } \\
\text { Patients }\end{array}$ & of \\
\hline 1. & $1-5 \mathrm{yr}$ & 12 & $40 \%$ \\
\hline 2. & $5-10 \mathrm{yr}$ & 9 & $30 \%$ \\
\hline 3. & $10-15 \mathrm{yr}$ & 9 & $30 \%$ \\
\hline
\end{tabular}

Maximum number of patients had been suffering since 1-5 years $(40 \%), 5-10$ years $(30 \%)$ and $10-15$ years $(30 \%)$.

9. Parity wise distribution:

Table Showing the Parity wise distribution of 30 patients:

\begin{tabular}{|l|l|l|l|}
\hline S.No & Parity & Number of Patients & \% of Distribution \\
\hline 1. & Nulliparous & $\mathbf{1 4}$ & $\mathbf{4 6 . 6 6}$ \\
\hline 2. & Primiparous & $\mathbf{0 5}$ & $\mathbf{1 6 . 6 7}$ \\
\hline 3. & Multiparous & $\mathbf{1 1}$ & $\mathbf{3 6 . 6 7}$ \\
\hline
\end{tabular}

Maximum number of patients were nulliparous (46.66\%) followed by multiparous $(36.67 \%)$, and primiparous $(16.67 \%)$

10. Deha prakruti wise distribution:

Table Showing the Deha prakruti wise distribution of 30 patients:

\begin{tabular}{|l|l|l|l|}
\hline S. No. & Deha prakriti & Number of Patients & \% of Distribution \\
\hline 1. & Vata-pitta & 17 & 56.66 \\
\hline 2. & Vata-kapha & 9 & 30.00 \\
\hline 3. & Kapha-pitta & 4 & 13.33 \\
\hline
\end{tabular}

Maximum number of patients were Vata-pittaja prakriti (56.66\%) followed by Vata- Kaphaja prakriti $(30.00 \%)$ and Kapha- Pittaja prakriti (13.33\%).

11. Family history wise distribution:

Table Showing the Family history wise distributionof 30 Patients:

\begin{tabular}{|l|l|l|l|}
\hline S.No. & Family history & Number of patients & \% distribution \\
\hline 1. & Present & 12 & $40 \%$ \\
\hline 2. & Absent & 18 & $60 \%$ \\
\hline
\end{tabular}

Maximum number of patients had no family history (60\%) and rest had family history (40\%) related to Kashtartava. 
12. Regularity of menstrual cycle wise distribution

Table Showing the Regularity of menstrual cycle wise distribution:

\begin{tabular}{|l|l|l|l|}
\hline S.No. & Regularity & Number of patients & \% distribution \\
\hline 1. & Regular & 22 & $73.33 \%$ \\
\hline 2. & Irregular & 08 & $26.67 \%$ \\
\hline
\end{tabular}

Maximum number of patients are having regular menstrual cycles $(73.33 \%)$ and rest are having irregular menstrual cycles $(26.67 \%)$.

13. Onset of pain wise distribution of 30 patients:

Table Showing the Onset of pain wise distribution of 30 patients:

\begin{tabular}{|l|l|l|l|}
\hline S.No. & Onset of pain & Number of patients & \%distribution \\
\hline 1. & Few hours Before menstruation & 18 & 60.00 \\
\hline 2. & After menstruation & 12 & 40.00 \\
\hline
\end{tabular}

Maximum number of patients are suffering from pain a few hours before menstruation $(60 \%)$ and rest are having pain after onset of menstruation (40\%).

14. Severity of pain wise distribution of 30 patients:

Table Showing the Severity of pain wise distribution of 30 patients:

\begin{tabular}{|l|l|l|l|}
\hline S.No. & Severity of pain & Number.of patients & \%distribution \\
\hline 1. & Grade 1 & 09 & 30 \\
\hline 2. & Grade 2 & 13 & 43.33 \\
\hline 3. & Grade 3 & 08 & 26.66 \\
\hline
\end{tabular}

Maximum number of patients are having Grade 2 Severity of pain (43.33\%) followed by Grade 1 Severity of pain (30\%).

15. Duration of Pain wise distribution of 30 patients:

Table Showing the Duration of Pain wise distribution of 30 patients:

\begin{tabular}{|l|l|l|l|}
\hline S.No. & Duration of pain & Number of patients & \%distribution \\
\hline 1. & $<12$ hours & 09 & 30 \\
\hline 2. & $12-24$ hours & 14 & 46.66 \\
\hline 3. & $>24$ hours & 07 & 23.33 \\
\hline
\end{tabular}

Maximum number of patients are having 12-24 hrs duration of pain (46.66\%) followed by $(30 \%)$ having $<12$ hrs duration of pain.

16. Effect of Shankhapani Rasa on subjective parameters in 30 patients:

Table Showing the Effect of Shankhapani Rasa on subjective parameters:

\begin{tabular}{|l|l|l|l|l|l|l|l|l|l|}
\hline Symptoms & $N$ & B.T & A.T & Mean & $\begin{array}{l}\text { Relief } \\
\%\end{array}$ & S.D & S.E & 't' & $p$ \\
\hline $\begin{array}{l}\text { Severity of } \\
\text { pain }\end{array}$ & 30 & 1.966 & 0.366 & 1.6 & $81.35 \%$ & 0.56 & 0.102 & 15.55 & 0.0003 \\
\hline Duration & 30 & 1.933 & 0.33 & 1.6 & $82.75 \%$ & 0.674 & 0.123 & 12.99 & 0.0002 \\
\hline
\end{tabular}

This table shows that Shankhapani Rasa provided statistically highly significant relief $(\mathrm{p}<0.01)$ of $81.35 \%$ in Severity of pain and $82.75 \%$ relief $(\mathrm{p}<0.01)$ in duration. 
Showing the overall Assessment of Clinical trial:

\begin{tabular}{|l|l|l|}
\hline Result & Number of patients & \% patients \\
\hline Cured & 21 & 70 \\
\hline Moderately cured & 06 & 20 \\
\hline Not cured & 03 & 10 \\
\hline
\end{tabular}

\section{Discussion:}

Dysmenorrhea i.e, pain during menstruation is becoming a challenging problem for women.It is commonly prevalent from the age of 16 to 30 years. The present study is under taken to find a complete and safe solution for Kashtartava through Ayurveda.

Ayurveda is an ocean and to take out a pearl i.e., treatment for any ailment is the work of Physician. It is mentioned in Ayurvedic classics that physician basing on his knowledge and condition of the patient must decide the drug to be administered. There are various formulations mentioned for treatment of Kashtartava. Shankhapani Rasa which was mentioned in Sahasra Yogam in Gutika prakarana consists of Kajjali, Chincha Ksara, Trikatu churna, Suddha Hingu, Suddha Vatsanabha, Saindhava lavana and Shankha Bhasma.

Maximum number of patients $(83.33 \%)$ belonged to Hindu religion. As the Study was conducted in Hindu predominant area, this finding was observed. Eventhough in the present study maximum number of patients $(50 \%)$ were married, they were having this problem since menarchae. Therefore the relation between marriage and dysmenorrhoea cannot be attributed. It is observed that maximum number, of patients were Housewifes $(50 \%)$. The patients who attended to our hospital were mainly housewifes. Maximum number of patients reported in present study were Nonvegetarians $(66.67 \%)$. Even though it is one of the upashaya of Kashtartava as they were taking it only once/twice in a month, it could not decrease the problem in those cases.

It is observed that maximum number of patients (40\%) was taking Katu-Tikta rasa predominant ahara. This shows the role of Katu rasa in the vitiation of vata, which is the chief cause in the manifestation of Kashtartava. Maximum number of patients $(80 \%)$ had Constipated bowels during menstruation, this reflects the vitiation of Apana Vata which is an important cause for Kashtartava. Present study shows that maximum percentage $(40 \%)$ of patients were suffering from Kashtartava since 1-5 years, this shows the chronicity of the disease.

Maximum numbers of patients registered were nulliparous (46.66\%).In these cases dysmenorrhoea might be due to the narrow pathway. Incidence according to prakriti showed that the majority of patients $(56.66 \%)$ were VataPittaja followed by Vata-Kaphaja (30\%). This observation supports the involvement of Vata Dosha in the pathogenesis of disease. In the present study $40 \%$ of patients were shown to have the family history of the disease, hence there might be the possibility of occurrence of the disease in the family.

All the patients were suffering from pain, either, 2-3 hours before the onset of menstruation or during menstruation. This also confirms the diagnosis as Primary dysmenorrhoea.

Statistically highly significant relief of $81.35 \%$, was observed in severity of pain. Statistically highly significant relief of $82.75 \%$, was observed in duration of pain.

Trikatu have deepana, pachana and shulaprasamana properties hence it helps in reducing the pain which is produced by ama (4). Vatsanabha has the properties madhura rasa, ushna virya and 
madhura vipaka., therefore acts as vata samaka (5). Hingu is having sula hara, Anulomaniya and Vata-Kapha hara properties (6). Shankha is having Sulahara, Gulmahara and udaramayahara properties (7). Saindhava lavana has rochana, deepana properties (8). As the Kshara is having lekhana property it scapes the excessive doshas and dhatus from its place and thus helps in relieving the pain which may be due to obstruction of the srotas by the vitiated doshas (9). Nimbuka has deepana, pachana and sulahara properties (10).

\section{Conclusion:}

Clinically the drug Shankhpani Rasa was found to cure $70 \%$ patients completely without remission of symptoms especially in Severity of pain and duration of pain after cessation of therapy, $20 \%$ of the patient had moderate relief in symptoms and only $10 \%$ of patients found no relief. Therapy was efficacious on all the major symptoms of the disease.

\section{References:}

1. Subaratnam

Arulkumaran,

V.Sivanesaratnam, Alokendu

Chatterjee, Pratap Kumar, Essentials of gynaecology, $2^{\text {nd }}$ edition, 2011, page no-58, 69.

2. Howkins \& Bourne, Shaws textbook of Gynaecology, $10^{\text {th }}$ edition, edited by
V.G padubidri shirish N.daftar, New Delhi, 1992, page no-310.

3. Krishnan A.K.V, Vaidyan \& A.S.Gopalapilla, Sahasrayogam, Gutika Yoga, $30^{\text {th }}$ Edition, edited by Vidhyarambha publishers, Mullakkal, 2011, page.no-61.

4. Sastry J.N.L., Dravyaguna vijnana, Volume-I, Chaukhambha orientalia, Varanasi, 2012, page.no-278.

5. Kamath S.D, Studies on Medicinal plants in Dhanvantari Nighantu, Chaukhambha prakashana, Varanasi, 2002, page.no-667.

6. Sastry J.N.L., Dravyaguna vijnana, Volume-I, Chaukhambha orientalia, Varanasi, 2012, page.no-255.

7. Indradev Tripati, Raja Nighantu, Dravyaguna prakashika tika, Suvarnadi varga by Chaukhambha Orientalia, Varanasi, 2010, page no452.

8. Govardansharma changaniArdha prakashika Hindi Vyakhya, Chaukhamdha, Varanasi, page no-141.

9. Vaidya Jadvji Trikamji Acharya, Susruta Samhita with Nibandha Sangraha comm. of Sri Dalhanacarya, Chaukhambha orientalia, Varanasi, 1997, page.no-45.

10. Indradev Tripati, Raja Nighantu, Dravyaguna prakashika tika, Amradi varga by Chaukhambha Orientalia, Varanasi, 2010, page no-375. 